\title{
Effectiveness of Shear and Flexural Repair and Strengthening of Box-section Steel Beams using CFRP Laminates
}

\author{
Mohamed R. Masoud, Mohamed A. Khalaf
}

\begin{abstract}
Steel structures are generally subjected to damages and defects due to different causes such as corrosion, fracture cracking, fire, buckling...etc. Damaged or defected parts may include girders, columns, welds, splices, base plates...etc. There is a wide range of techniques used for repair and strengthening starting with using protective coatings and ending up with full replacement of the damaged parts.

Fiber Reinforced Plastic (FRP) laminates are widely used now in the field of repair and strengthening of different types of structures (reinforced concrete structures, steel structures, masonry structures, timber structures....etc.). The main goal of this research is to investigate the effectiveness of using Carbon Fiber Reinforced Plastic (CFRP) laminates in repair and strengthening of steel beams (in both flexural and shear). A total of five box-section steel beams were tested in three point load flexure test to determine the stiffness and ultimate load carrying capacity of the strengthened and repaired beams using CFRP laminates and compare the obtained results for these beams with those of the fifth beam which used as a control beam (without CFRP laminates). Test results showed that the effectiveness of using CFRP laminates for repair and strengthening of steel beams depends mainly on the obtained modes of failure. Highest effectiveness was obtained in tension failure modes while almost no effectiveness obtained in compression failure modes.
\end{abstract}

Keywords: CFRP laminate; Steel beam; Box section; Repair; Strengthening.

\section{INTRODUCTION}

Traditional strengthening technique by using steel sections has a good achievement to increase strength and stiffness of steel structural elements. However, this technique has many disadvantages such as it is a labor and cost intensive coupled with the needed onsite welding and drilling operations; it is considered a time consuming technique and consequently can causes a traffic disruption in highway roads and bridges. Moreover, many problems are accompanied with this technique such as the heavy weight of steel plates with a large thickness, carrying and lifting difficulty during construction,

Revised Manuscript Received on February 05, 2020.

* Correspondence Author

Mohamed R. Masoud* , Assistant Prof., Department of Structural Engineering, Faculty of Engineering, Ain Shams University, Cairo, Egypt. E-Mail : mohamed_abdelmagid@eng.asu.edu.eg

Mohamed A. Khalaf, Professor, Department of Structural Engineering, Faculty of Engineering, Ain Shams University, Egypt. E-Mail: Mohamed_khalaf@eng.asu.edu.eg

(C) The Authors. Published by Blue Eyes Intelligence Engineering and Sciences Publication (BEIESP). This is an open access article under the CC BY-NC-ND license (http://creativecommons.org/licenses/by-nc-nd/4.0/) a lot of machines and equipment, rust and corrosion problems in iron metal and finally fatigue problems due to stress concentration and weld effect. Obviously, there is a need to find durable strengthening materials and rapid strengthening techniques. Fiber reinforced polymers (FRP) are latest available alternative materials. FRP became an attractive material in the strengthening field of steel buildings because of its stunning mechanical and physical properties [1]. Many studies have recently been conducted on the strengthening of steel elements by bonding CFRP laminate to the steel surface.

Flexural strengthening of steel elements using FRP had investigated extensively in many previous studies [2-6]. Another group of studies has focused on strengthening of steel web by CFRP which dramatically increases the web crippling capacity exclusively for those with large web slenderness ratio. Test results proved that there was an increase in the web-buckling capacity especially by bonding CFRP laminates on both sides of the web [7-10].

Shear strength of steel I-beams is controlled mainly by the capacity of the web plate. The collapse of the web plate because of yielding or elastic buckling depends on the slenderness ratio of the web plate. The elastic buckling of the slender web plates is directly related to the level of the major compressive stresses induced within the high shear zones of the beam. Strengthening of steel web by using CFRP materials has the chance to decrease the stress level in the steel web, and subsequently increasing the web shear carrying capacity [2]. Some researchers have demonstrated different techniques for strengthening of steel webs subjected to shear by CFRP. Patnaik et al. (2008) [11] has published results of an analytical and experimental program focused on shear strengthening of steel built-up I-beams. In this research three steel beams were designed to fail in shear. Two were strengthened by bonding CFRP to the web plates, while the third one was kept un-strengthened control beam for comparison purpose. Test results confirmed the effectiveness of shear strengthening application by increasing the shear resistance of the steel beam up to $26 \%$.

Okeil et al. [12-14] has improved the lateral stiffness of buckling-prone steel I-beams by bonding pultruded GFRP sections. Steel I-beams were designed to fail in shear buckling. Thin walled steel web plates were strengthened by GFRP T-shaped in a direction that contributes to the lateral

stiffness of the steel web plates more than the in-plane strength as in the popular practice in the most FRP strengthening cases.

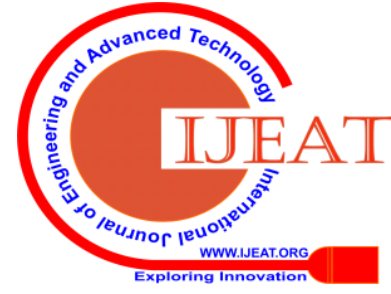


The strengthened specimen experienced shear buckling under $56 \%$ higher load compared with the control un-strengthened specimen. However, the performance of the strengthened specimen was more brittle compared with the control one. This study was continued by Babaizadeh (2012) [15] using Finite Element analysis. Results of the finite element analysis showed that strengthening of steel beams with different flange width can result in the growth of shear capacity up to $66 \%$ for square shear zones and up to $36 \%$ for the rectangular shear zones. Furthermore, results designated that GFRP stiffeners are more effective than steel stiffener in terms of improving the shear resistance of the strengthened steel beam. However, failures modes of the GFRP stiffened beams are less ductile compared with those of the un-stiffened or the traditionally steel stiffened beams.

Narmashiri et al. (2010) [16] has examined the success of using CFRP as a shear strengthening system. Steel beams were strengthened by applying CFRP on one or both sides of the web using different ratios of CFRP area on the web. Five steel I-section beams were tested. Two beams were strengthened on both sides of the web with the CFRP ratios of 0.72 and 0.48 . Two beams were strengthened on one side of web with the CFRP ratios of 0.72 and 0.48 . Last beam was kept as un-strengthened control beam to be used for comparison purpose. Results clearly showed that the externally bonded CFRP could increase the shear resistance of the steel strengthened I-beam up to 51\%. Furthermore, both CFRP ratios for both sides of web almost had similar level of shear strengthening level.

Elyas Ghafoori, Masoud Motavalli (2015) [23] have studied the elastic behavior of steel beams strengthened by normal, high and ultra-high modulus CFRP strips using bonded and un-bonded systems. Six steel beams strengthened by CFRP strips and one un-strengthened beam (control beam for comparison purposes) were tested statically until failure using four-point load arrangement. The six steel beams were strengthened using normal modulus (NM), high modulus (HM) and ultra-high modulus (UHM) CFRP strips with nominal modulus of elasticity ranging from 165 to $440 \mathrm{GPa}$. Each type of CFRP strips was attached to the steel beams using bonded reinforcement (BR) and un-bonded reinforcement (UR) systems. The main goal of this research was to study the stress distribution along the beam bottom flange when the BR and the UR systems are used for strengthening. All beams were failed due to lateral torsional buckling. The obtained test results have shown that strengthening using bonded UHM strips could increase the stiffness of the composite section so that the steel profile has yielded prior to buckling and larger reinforcement effectiveness was then achieved.

This study was continued both experimentally and numerically by Elyas Ghafoori, Masoud Motavalli (2015) [24] by considering the lateral-torsional buckling of steel beams strengthened by normal modulus CFRP strips. Seven steel beams, (including un-strengthened control beam), were tested statically until failure. Six steel beams were strengthened by bonded and un-bonded CFRP strips. For each type, three steel beams were strengthened by CFRP strips with three different pre-stressing levels $(0 \%, 20 \%$ and $40 \%$ ) and tested till failure. Test results showed that strengthening of steel beams using CFRP strips increases the elastic stiffness of the beams almost the same for both bonded and un-bonded systems compared to the control beam. Pre-stressing of CFRP strips almost has no effect on the stiffness of the strengthened beams but substantially influences the buckling strength. High values of pre-stressing levels do not necessarily lead to an increased buckling strength. In most of the tests, beams strengthened with un-bonded CFRP strips showed slightly higher strength than those strengthened by bonded CFRP strips.

\section{OBJECTIVES}

The main objective of this research work is to investigate the effectiveness of using CFRP laminates for the purpose of repair and strengthening of box-section steel beams (in both flexural and shear). This objective will be achieved by comparing the stiffness and ultimate load carrying capacity of the strengthened and repaired beams (using CFRP) with those of a similar beam without CFRP

\section{MATERIALS AND TEST SPECIMENS}

\section{A. CFRP MATERIALS}

The Carbon Fibers used for strengthening and repair of steel beams were unidirectional carbon fibers laminates strengthening system produced by Sika (under the trade name :Sika Wrap HEX-230 C). The matrix material used for bonding the Carbon Fibers to the steel surface was produced also by Sika (under the trade name: Sikadur 330) of $1 \mathrm{~mm}$ thickness. Tables (1) and (2) give all the properties given by Sika for carbon fibers and matrix material, respectively.

Table-I: Properties of Carbon Fibers

(Given by the manufacturer)

\begin{tabular}{|c|c|}
\hline Property & Value \\
\hline \hline Orientation & $0^{\circ}$ (Unidirectional) \\
\hline Area Weight & $225 \mathrm{gm} / \mathrm{m}^{2}$ \\
\hline Tensile Strength & $3500 \mathrm{~N} / \mathrm{mm}^{2}$ \\
\hline Tensile Modulus & $230,000 \mathrm{~N} / \mathrm{mm}^{2}$ \\
\hline Max. Elongation & $1.5 \%$ \\
\hline
\end{tabular}

Table-II: Properties of Resin Material (Given by the manufacturer)

\begin{tabular}{|c|c|}
\hline Property & Value \\
\hline Appearance & $\begin{array}{l}\text { Comp. A : White } \\
\text { Comp. B : Grey }\end{array}$ \\
\hline Density & $1.31 \mathrm{Kg} / \mathrm{L}$ (mixed) \\
\hline Mixing Ratio & $\mathrm{A}: \mathrm{B}=4: 1$ (By weight) \\
\hline Viscosity & Pasty Not Flowable \\
\hline Application Temp. & $\begin{array}{c}15^{\circ} \text { to } 35^{\circ} \\
\text { (Ambient \& Substrate) }\end{array}$ \\
\hline Tensile Strength & $\begin{array}{c}30 \mathrm{~N} / \mathrm{mm}^{2} \\
\left(\text { Cured } 7 \text { days at } 23^{\circ} \text { ) }\right.\end{array}$ \\
\hline Tensile Modulus & $\begin{array}{c}3800 \mathrm{~N} / \mathrm{mm}^{2} \\
\left(\text { Cured } 7 \text { days at } 23^{\circ} \text { ) }\right.\end{array}$ \\
\hline
\end{tabular}




\section{B. STEEL BEAMS}

The five steel beams used in the experimental study have a square box cross section of outside dimensions 10x10 cm and a thickness of $0.22 \mathrm{~cm}$. The total length of the beams is 120 $\mathrm{cm}$ while the loading span is $100 \mathrm{~cm}$.

The beams were tested using three point load flexure test where the applied load was acting at the mid-span using a hydraulic jack through a loading steel plate of dimensions 10x6x1 $\mathrm{cm}(6 \mathrm{~cm}$ along the beam axis and $10 \mathrm{~cm}$ across the width of the upper flange). The two bearing plates used at supports were of the same dimensions as the aforementioned loading plate. The bearing plates were rested on $2.5 \mathrm{~cm}$ diameter steel bars. Dimensions of the steel beams are as shown in Figure (1).

Tension test was carried out on three test specimens cut from the overhanging parts of the steel beams according to ESS $76 / 1969$ in order to determine the tensile properties of the steel. The average measured tensile strength is $52.5 \mathrm{Kg} / \mathrm{mm} 2$ and the average elongation percentage is $14.6 \%$, as given in Table (3). It is important to note that there is no yielding observed during the tension test.

Table-III: Measured Properties of steel

\begin{tabular}{|c|c|c|}
\hline $\begin{array}{l}\text { Specimen } \\
\text { No. }\end{array}$ & $\begin{array}{c}\text { Tensile } \\
\text { Strength } \\
\left(\mathrm{Kg} / \mathrm{mm}^{2}\right)\end{array}$ & $\begin{array}{c}\text { Ductility } \\
\text { (\% Elongation) }\end{array}$ \\
\hline 1 & 52.3 & 15.6 \\
\hline 2 & 52.0 & 14.2 \\
\hline 3 & 53.1 & 14.1 \\
\hline Average & 52.5 & 14.6 \\
\hline
\end{tabular}

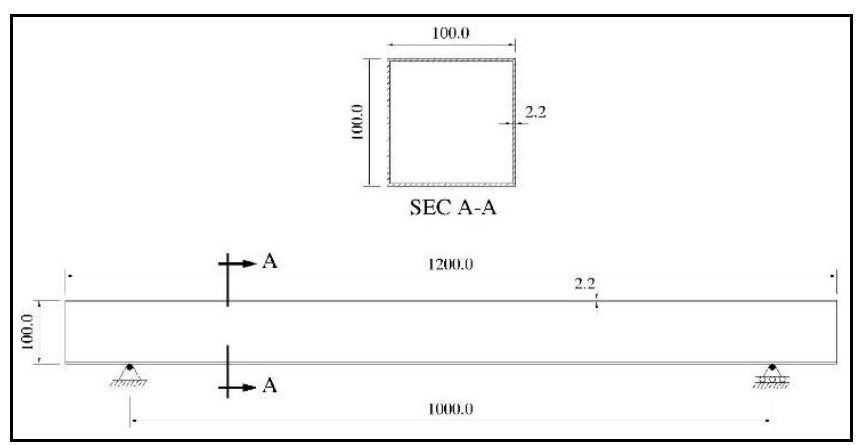

Fig. 1.Dimensions of steel beams in mms

One of the beams was used as a control beam for comparison and designated as B1; no CFRP sheets were used for this beam. Two beams were strengthened using carbon fiber reinforced plastic sheets; one was strengthened in flexure and designated as B2 while the second was strengthened in both flexure and shear and designated as B3. For beam B2, the CFRP sheet was applied on the tension side only (i.e. the bottom flange). For beam B3, CFRP sheet was applied on three sides (the bottom flange and the two webs). Figure (2) shows the location of carbon sheets applied at bottom flange or bottom flange + two webs.

Beam B4 was cut horizontally in the tension flange across the full width at the mid-span and then repaired using CFRP sheet bonded to the whole surface of the bottom flange along the beam length. Beam B5 was cut horizontally in the tension flange across the full width at the mid-span and vertically in the two webs at $1 / 5$ span (i.e. at $20 \mathrm{cms}$ from the support) in both sides of the beam; beam B5 then repaired using CFRP sheet bonded to the whole three surfaces of the bottom flange and the two webs along the beam length. CFRP sheets were bonded to the steel beams using the resin material SikaDur 330 as mentioned before. Table (4) gives the location of bonded CFRP sheets of beams B2, B3, B4, and B5 and the location of cut for beams B4 \& B5.

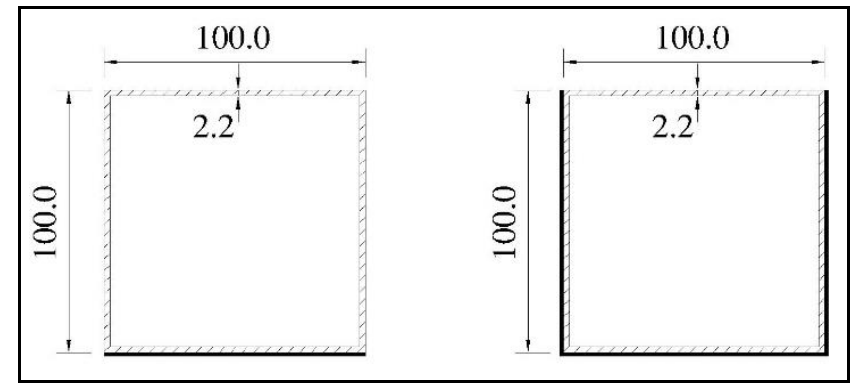

(a)

(b)

Fig. 2.Location of CFRP (Dimensions in mms) (a): Bottom flange \& (b): Bottom flange +webs)

Table-IV: Identification of beams

\begin{tabular}{|c||c|c|c||}
\hline $\begin{array}{c}\text { Beam } \\
\text { Code }\end{array}$ & Identification & $\begin{array}{c}\text { Side of FRP } \\
\text { applied on }\end{array}$ & Location of cut \\
\hline \hline B1 & Control & ----- & ------ \\
\hline B2 & $\begin{array}{c}\text { Strengthening } \\
\text { (Flexure) }\end{array}$ & $\begin{array}{c}\text { Bottom } \\
\text { Flange }\end{array}$ & ------ \\
\hline B3 & $\begin{array}{c}\text { Strengthening } \\
\text { (Flexure \& } \\
\text { Shear) }\end{array}$ & $\begin{array}{c}\text { Bottom } \\
\text { Flange }+ \\
\text { Webs }\end{array}$ & ----- \\
\hline B4 & $\begin{array}{c}\text { Repair } \\
\text { (Flexure) }\end{array}$ & $\begin{array}{c}\text { Bottom } \\
\text { Flange }\end{array}$ & $\begin{array}{c}\text { Bottom Flange } \\
\text { at mid-span }\end{array}$ \\
\hline B5 & $\begin{array}{c}\text { Repair } \\
\text { (Flexure \& } \\
\text { Shear) }\end{array}$ & $\begin{array}{c}\text { Bottom } \\
\text { Flange }+\end{array}$ & $\begin{array}{c}\text { Bottom Flange } \\
\text { at mid-span }+ \\
\text { Webs }\end{array}$ \\
\hline
\end{tabular}

\section{TEST RESULTS}

The five steel beams were tested in flexure using three point load configuration where the load was applied at the mid-span as mentioned earlier. The mid-span deflection was recorded using a dial gauge of $0.01 \mathrm{~mm}$ sensitivity. The values of mid-span deflections were recorded at every load interval which was 0.20 ton till about 3.6 tons and the dial gauge was then removed to continue loading until failure. The ultimate load was recorded for each beam together with the mode of failure. Table (5) gives the load/mid-span deflection test results, failure loads,

calculated overall stiffness, and the modes of failure for all the tested beams. Figure (3) also shows the load/mid-span deflection test results for all the tested beams.

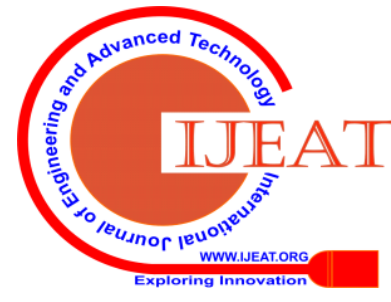


Table-V: Test results of beams

\begin{tabular}{|c|c|c|c|c|c|}
\hline \multirow{2}{*}{$\begin{array}{l}\text { Load } \\
\text { (ton) }\end{array}$} & \multicolumn{5}{|c|}{ Mid-span deflection (mm) } \\
\hline & B1 & B2 & B3 & B4 & B5 \\
\hline 0.5 & 0.39 & 0.20 & 0.48 & 1.12 & 1.15 \\
\hline 1.0 & 0.93 & 0.81 & 0.94 & 1.60 & 1.65 \\
\hline 1.2 & 1.14 & 0.95 & 1.10 & 1.81 & 1.90 \\
\hline 1.4 & 1.29 & 1.12 & 1.32 & 1.97 & 2.01 \\
\hline 1.6 & 1.35 & 1.28 & 1.48 & 2.12 & 2.16 \\
\hline 1.8 & 1.47 & 1.44 & 1.65 & 2.30 & 2.36 \\
\hline 2.0 & 1.63 & 1.63 & 1.82 & 2.45 & 2.46 \\
\hline 2.2 & 1.79 & 1.79 & 1.98 & 2.61 & 2.71 \\
\hline 2.4 & 1.94 & 1.98 & 2.12 & 2.80 & 2.93 \\
\hline 2.6 & 2.13 & 2.16 & 2.29 & 2.97 & 3.06 \\
\hline 2.8 & 2.28 & 2.30 & 2.46 & 3.13 & 3.21 \\
\hline 3.0 & 2.41 & 2.47 & 2.62 & 3.25 & 3.36 \\
\hline 3.2 & 2.62 & 2.68 & 2.84 & 3.48 & 3.61 \\
\hline 3.4 & 2.81 & 2.92 & 3.03 & 3.71 & 3.90 \\
\hline 3.6 & 3.03 & 3.21 & 3.22 & 3.94 & 4.09 \\
\hline $\begin{array}{c}\text { Failure } \\
\text { Load } \\
\text { (ton) }\end{array}$ & $\begin{array}{c}4.4 \\
(100 \%)\end{array}$ & $\begin{array}{c}4.3 \\
(98 \%)\end{array}$ & $\begin{array}{c}4.5 \\
(102 \%)\end{array}$ & $\begin{array}{c}4.0 \\
(91 \%)\end{array}$ & $\begin{array}{c}3.8 \\
(86 \%)\end{array}$ \\
\hline $\begin{array}{l}\text { Overal } \\
1 \text { Stiff. } \\
(\mathrm{t} / \mathrm{mm})\end{array}$ & $\begin{array}{c}1.2082 \\
(100 \%)\end{array}$ & $\begin{array}{l}1.1938 \\
(99 \%)\end{array}$ & $\begin{array}{l}1.1480 \\
(95 \%)\end{array}$ & $\begin{array}{l}0.8586 \\
(71 \%)\end{array}$ & $\begin{array}{l}0.8303 \\
(69 \%)\end{array}$ \\
\hline 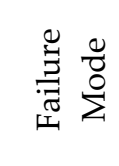 & 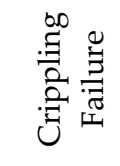 & 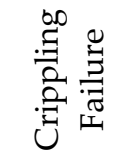 & 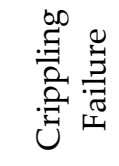 & 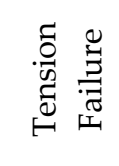 & 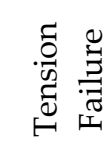 \\
\hline
\end{tabular}

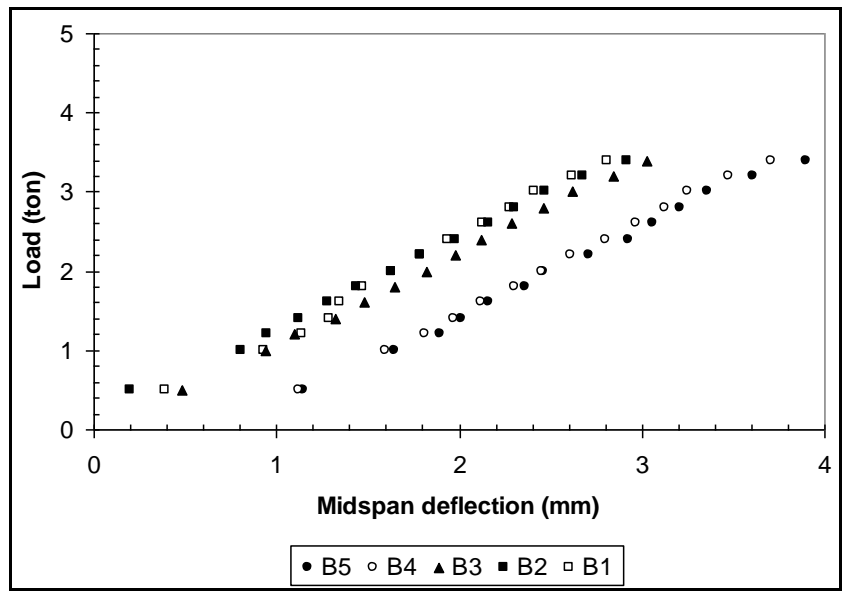

Fig. 3. Load / Mid-span deflection test results

\section{DISCUSSION OF TEST RESULTS}

- $\quad$ As mentioned earlier, beam B2 is strengthened only in flexure by bonding CFRP laminates to the whole surface of the bottom flange and beam B3 is strengthened in both flexure and shear by bonding CFRP laminates to the whole three surfaces of the bottom flange and the two webs as shown in Figure (2). The load/mid-span deflection $(\mathrm{P} / \Delta)$ of all beams was measured up to 3.6 ton, which is about $82 \%$ from the failure load of control beam B1; the recorded values of load and mid-span deflection were linear up to 3.6 tons as shown in Figure (3). Figure (4) shows a comparison between the measured $(\mathrm{P} / \Delta)$ for all beams as a percentage from that of control beam B1. As shown in that figure, the stiffness of beams B2 and B3 are 99\% and 95\%, respectively from that of control beam which can be considered almost the same. This result indicates that presence of CFRP laminates almost has no effect on the stiffness; or in other words CFRP laminates did not increase the stiffness of the steel beams. Contribution of CFRP to the overall beam stiffness is negligible because the stiffness of the CFRP section itself is very small compared to that of the steel beam.

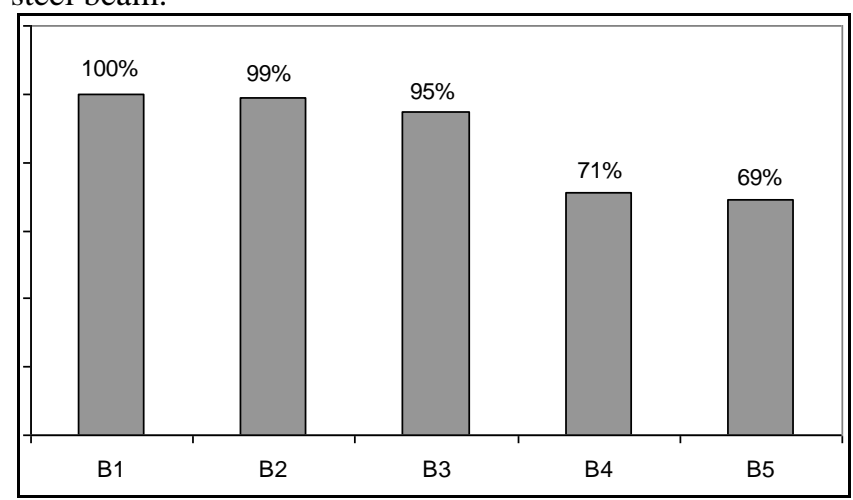

Fig. 4.Stiffness of the beams as a percentage of the control beam B1

- Figure (5) shows a comparison between the failure loads for all beams as a percentage of that of control beam B1. As shown in that figure, the failure loads of beams B2 and B3 are $98 \%$ and $102 \%$, respectively of that of control beam which can be considered almost the same. Beams B2 and B3 failed by crippling exactly like what happened to the control beam as given before in Table (4). This result indicates that the presence of CFRP laminates almost has no effect on the value of the failure load; or in other words CFRP laminates did not increase the load carrying capacity of the steel beams when the mode of failure is compression mode due to crippling.

- As mentioned earlier, beam B4 was cut horizontally across the full width of the bottom flange at the mid-span through the whole thickness (which is $0.22 \mathrm{cms}$ ) to represent a very severe crack in the tension flange at the critical section of the maximum bending moment. CFRP laminates was bonded to the whole surface of the bottom flange along the beam length. Beam B5 was cut horizontally across the bottom flange at the mid-span and vertically in the two webs at $1 / 5$ span at both sides of the beam in the region of constant shear force. CFRP laminates was added to the bottom flange and the two webs along the beam length. As shown in Figure (4), the overall stiffness of beams B4 and B5 are about 70\% of that of control beam due to the crack (or cut) in the tension flange. Figure (5) shows that the failure loads of beams B4 and B5 are 91\% and 86\%, respectively of that of control beam.

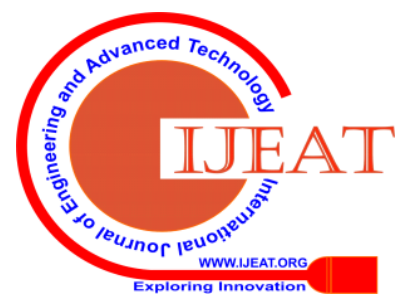

Published By:

Blue Eyes Intelligence Engineering

\& Sciences Publication 
The mode of failure of beams B4 and B5 is a tension failure in CFRP sheets at the mid-span at the location of the artificial crack (cut). This result indicates that CFRP sheets work efficiently to resist the tensile stresses up to failure. This important result is obtained by using only one layer of CFRP laminates for repair purpose; if more than one layer were used, the value of the failure load would be increased. It should be noted here that there was no slippage between CFRP sheets and the steel surface till failure of all the beams, which indicates good efficiency of the used resin material.

- The values of stiffness of beams B4 and B5 and also the values of failure loads of these beams are very close as mentioned above; i.e. there is no big difference between the general behaviors of these two beams. This can be attributed to the span to depth ratio which is equal to 10 (i.e. $\mathrm{L} / \mathrm{d}=10$ ) which means that the effect of shear is not as strong as that of flexure. If short beams were used, the obtained results may be changed.

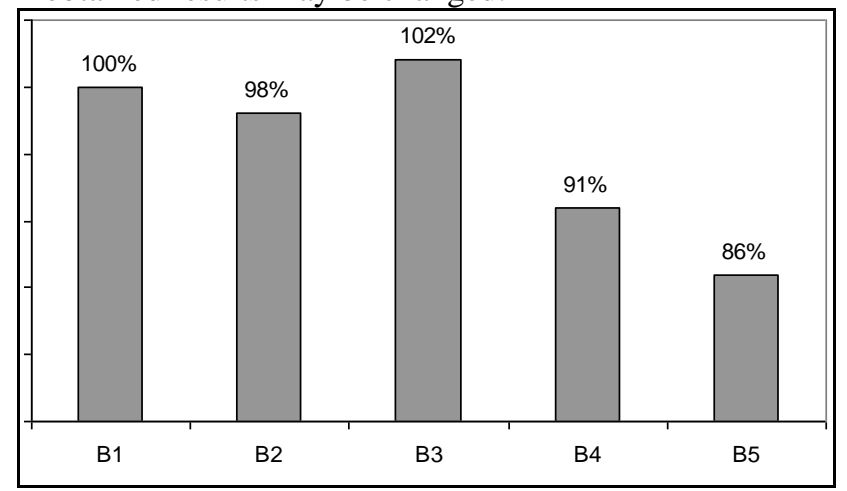

Fig. 5.Load carrying capacity of tested beams as a percentage of the control beam $B 1$

\section{CONCLUSIONS}

Based on the obtained test results and the previous discussion, the following points can be easily concluded:

- The effectiveness of using CFRP laminates for strengthening of steel beams depends mainly on the obtained mode of failure.

- CFRP laminates are not effective in the cases of compression failure modes such as crippling.

- Carbon FRP laminates are effective for repair of tension flange and web cracks; failure loads were between $86 \%$ and $91 \%$ of that of control beam which considered reasonable effectiveness.

- The stiffness of the repaired beams was about $70 \%$ of that of the control beam which is not as effective as the case of failure loads.

\section{REFERENCES}

1. Shaat, A., Schnerch, D., Fam, A., and Rizkalla, S. 2004. Retrofit of steel structures using fiber-reinforced polymers (FRP) State-of-the-art. Presented at Transportation Research Board (TRB) Annual Meeting, Washington, DC, January 11-15.

2. Zhao, X.L., FRP-Strengthened Metallic Structures: CRC Press Taylor \& Francis Group, LLC, 2014

3. A. Shaat and A. Fam, "Axial loading tests on short and long hollow structural steel columns retrofitted using carbon fiber reinforced polymers," Canadian Journal of Civil Engineering, vol. 33, pp. 458-470, 2006.

4. N. Silvestre, B. Young, and D. Camotim , "Non-linear behavior and load-carrying capacity of CFRP-strengthened lipped channel steel columns," Engineering Structures, vol. 30, pp. 2613-2630, 2008.
5. A. Shaat and A. Z. Fam, "Slender steel columns strengthened using high-modulus CFRP plates for buckling control," Journal of Composites for Construction, vol. 13, pp. 2-12, 2009.

6. K. A. Harries, A. J. Peck, and E. J. Abraham, "Enhancing stability of structural steel sections using FRP," Thin-Walled Structures, vol. 47, pp. 1092-1101, 2009.

7. X.-L. Zhao, D. Fernando, and R. Al-Mahaidi, "CFRP strengthened RHS subjected to transverse end bearing force," Engineering structures, vol. 28, pp. 1555-1565, 2006.

8. X. Zhao and R. Al-Mahaidi, "Web buckling of light steel beams strengthened with CFRP subjected to end-bearing forces," Thin-walled structures, vol. 47, pp. 1029-1036,2009.

9. X. Zhao, "Tests on CFRP strengthened open sections subjected to end bearing forces," in Proceedings of Asia Pacific conference on FRP in structures. Seoul, Korea, 2009.

10. J. Aguilera and A. Fam, "Bonded FRP plates for strengthening rectangular hollow steel section T-joints against web buckling induced by transverse compression," Journal of Composites for Construction, vol. 17, pp. 421-432, 2012.

11. A. Patnaik, C. Bauer, and T. Srivatsan, "The extrinsic influence of carbon fiber reinforced plastic laminates to strengthen steel structures," Sadhana, vol. 33, pp. 261-272, 2008.

12. A. M. Okeil, Y. Bingol, and M. R. Ferdous, "Novel technique for inhibiting buckling of thin-walled steel structures using pultruded glass FRP sections," Journal of composites for construction, vol. 13, pp 547-557, 2009.

13. A. Okeil, T. Ulger, and H. Babaizadeh, "Effect of adhesive type on Strengthening By Stiffening for shear-deficient thin-walled steel structures," International Journal of Adhesion and Adhesives, vol. 58, pp. 80-87, 2015.

14. A. Okeil, T. Ulger, and H. Babaizadeh, "Performance of thin-walled steel beams strengthened with GFRP stiffeners bonded using two different adhesives," 2014

15. H. BabaizadehRoshanfekr, "FRP Stiffener Efficiency Coefficient for SBS Shear Strengthening Applications," Master of Science, Department of Civil and Environmental Engineering, Louisiana State University, 2012.

16. K. Narmashiri, M. Z. Jumaat, and N. R. Sulong, "Shear strengthening of steel I-beams by using CFRP strips," Scientific Research and Essays, vol.5, pp. 2155-2168, 2010.

17. Standard Test Methods for Tension Testing of Metallic Materials: ASTM E8/E8M.

18. Standard Test Method for Tensile Properties of Polymer Matrix Composite Materials: ASTM D 3039/D 3039M.

19. Standard Test Methods of testing cement - Part 1: Determination of strength EN-196

20. Standard Test Method for Lap Shear Adhesion for Fiber Reinforced Plastic (FRP) Bonding materials - ASTM D-5868-01 (2014) -

21. Standard Test Methods for tension loading testing for Double Lap Shear adhesive joints. ASTM D-3528

22. Hazim AL-Talawy, "Shear strengthening of steel I-beams using locally available CFRP", M.Sc. thesis, Structural Engineering department, Faculty of Engineering, Ain-Shams University, Cairo, Egypt, 2018.

23. Elyas Ghafoori, Masoud Motavalli, "Normal, high and ultra-high modulus carbon fiber-reinforced polymer laminates for bonded and un-bonded strengthening of steel beams", Materials and Design 67 (2015) 232-243.

24. Elyas Ghafoori, Masoud Motavalli, "Lateral-torsional buckling of steel I-beams retrofitted by bonded and un-bonded CFRP laminates with different pre-stress levels: Experimental and numerical study", Construction and Building Materials 76 (2015) 194-206.

25. I. A. Amer, "Improving the end anchorage of strengthened steel I-beams using locally available CFRP laminates", M.Sc. thesis, Structural Engineering department, Faculty of Engineering, Ain-Shams University, Cairo, Egypt, 2016.

26. Elyas Ghafoori, Masoud Motavalli, "Innovative CFRP-Prestressing System for Strengthening Metallic Structures", Journal of Composite for Construction, Volume 19 Issue 6 - December 2015.

27. "Specification for structural steel building" - American Institute of Steel Construction (AISC) - Version 2016.

28. Nanni A. "Fiber Reinforced Plastic materials" Proceedings from the first middle-east workshop on structural composites, Sharm El-Shiekh, Egypt, June 1996.

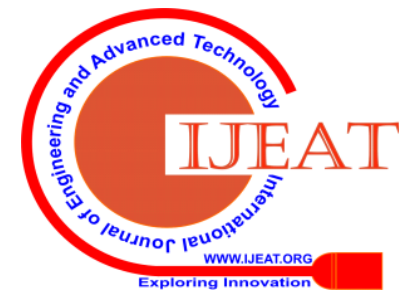


29. Ballinger C.A. "Advanced Composites in the Construction Industry" Proceedings from the 37th. International SAMPE symposium, March 1992.

30. Sami Rizkalla "Use Of High Modulus Carbon Fiber Reinforced Polymers For Strengthening Steel Structures" Proceedings from the HBRC Conference, Cairo, Egypt, Dec. 2003.

31. Gibson R.L. "Principles of composite material mechanics" Text book, McGraw-Hill Series in Mechanical Engineering, ISBN 0-07-023451-5, 1994.

32. Hosny, Abdel-Hady and Mahfouz, Ibrahim “ Introduction and Overview to Advanced Composite Materials" Proceedings from the first middle-east workshop on structural composites, Sharm El-Shiekh, Egypt, June 1996, pp. I-XIX.

33. Mohamed A. Khalaf "REPAIR AND STRENGTHENING OF BOX-SECTION STEEL BEAMS USING CARBON FIBERS REINFORCED PLASTIC SHEETS" Ain Shams University scientific bulletin, June 2005..

\section{AUTHORS PROFILE}

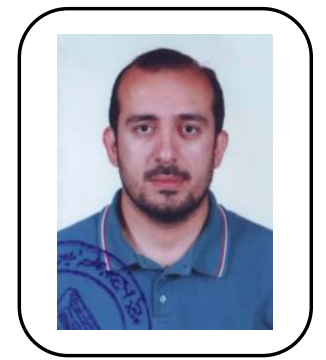

Mohamed R. Masoud was graduated from Structural Engineering department, Faculty of Engineering, Ain Shams University, Cairo, Egypt in June1991. He got his M.Sc. and Ph.D. from the same department in 1998 and 2007 respectively. Now he works as an Assistant Professor in the same department. His scientific research interest is in the field of performance and durability of concrete, corrosion of steel reinforcement, and repair and strengthening of $\mathrm{RC}$ structures. In addition He is a professional engineer in the Egyptian general organization of educational buildings. He works in the field of repair and strengthening of such buildings.

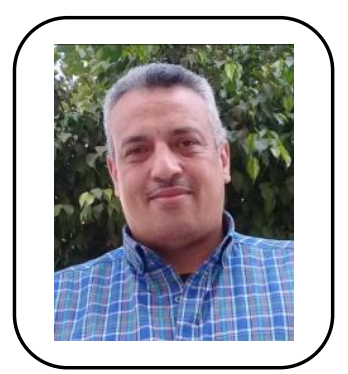

Mohamed A. Khalaf was graduated from Structural Engineering department, Faculty of Engineering, Ain Shams University, Cairo, Egypt in June1990. He got his M.Sc. from the same department in 1993 in the field of cathodic protection of steel reinforcement. He got his Ph.D from Drexel University, PA, USA in 2001 in the field of fatigue behavior of GFRP pultruded beams. .Now he is a Professor of properties and strength of materials in the same department. His scientific research interest is in the fields of protection against corrosion of steel reinforcement, repair and strengthening of RC structures and applications of FRP materials in the structural field. 